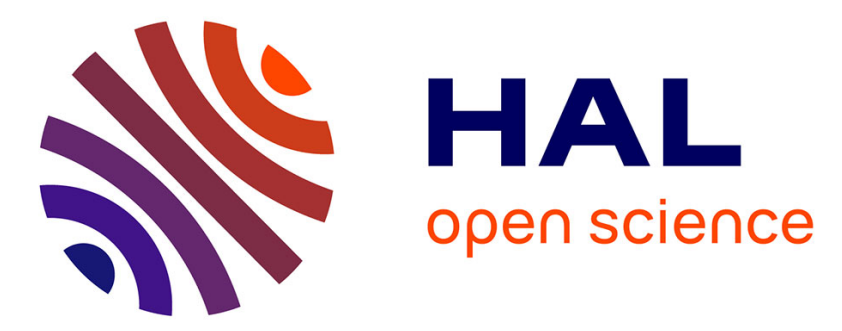

\title{
Meal frequency changes the basal and time-course profiles of plasma nutrient concentrations and affects feed efficiency in young growing pigs
}

Thierry Le Naou, Nathalie Le Floc'H, Isabelle Louveau, Jaap J. van Milgen, Florence Gondret

\section{To cite this version:}

Thierry Le Naou, Nathalie Le Floc'H, Isabelle Louveau, Jaap J. van Milgen, Florence Gondret. Meal frequency changes the basal and time-course profiles of plasma nutrient concentrations and affects feed efficiency in young growing pigs. Journal of Animal Science, 2014, 92 (5), pp.2008-2016. 10.2527/jas.2013-7505 . hal-01210577

\section{HAL Id: hal-01210577 \\ https://hal.science/hal-01210577}

Submitted on 28 May 2020

HAL is a multi-disciplinary open access archive for the deposit and dissemination of scientific research documents, whether they are published or not. The documents may come from teaching and research institutions in France or abroad, or from public or private research centers.
L'archive ouverte pluridisciplinaire HAL, est destinée au dépôt et à la diffusion de documents scientifiques de niveau recherche, publiés ou non, émanant des établissements d'enseignement et de recherche français ou étrangers, des laboratoires publics ou privés. 


\section{JOURNAL OF ANIMAL SCIENCE}

The Premier Journal and Leading Source of New Knowledge and Perspective in Animal Science

\section{Meal frequency changes the basal and time-course profiles of plasma nutrient concentrations and affects feed efficiency in young growing pigs \\ T. Le Naou, N. Le Floc'h, I. Louveau, J. van Milgen and F. Gondret}

J ANIM SCI 2014, 92:2008-2016.

doi: 10.2527/jas.2013-7505 originally published online March 18, 2014

The online version of this article, along with updated information and services, is located on the World Wide Web at:

http://www.journalofanimalscience.org/content/92/5/2008 


\title{
Meal frequency changes the basal and time-course profiles of plasma nutrient concentrations and affects feed efficiency in young growing pigs ${ }^{1}$
}

\author{
T. Le Naou, N. Le Floc'h, I. Louveau, J. van Milgen, and F. Gondret ${ }^{2}$ \\ INRA, UMR1348 Pegase, Saint-Gilles, France; and Agrocampus-Ouest, UMR1348 Pegase, Rennes, France
}

\begin{abstract}
Ingested dietary nutrients and feed energy are partitioned among tissues to sustain body growth. Based on the respective costs of the various metabolic pathways allowing use and storage of feed energy into cells, it may be theorized that daily meal frequency could affect growth, body composition or feed efficiency. This study aimed to determine the effects of daily meal frequency on nutrient partitioning, tissue metabolism and composition, and performance. Young growing pigs ( $30 \mathrm{~kg} \mathrm{BW})$ were offered a same amount of feed either in 2 (M2, $n=15)$ or 12 (M12, $n=$ 16) meals per day during a 3-wk interventional period. Animals fed twice a day had an accelerated weight gain $(+6.4 \%, P<0.05)$ and exhibited a greater G:F $(+4 \%$, $P=0.03)$ than animals fed 12 meals per day during this period. Basal plasma concentrations of glucose, lactate, triglyceride, urea, and leptin were lower $(P<0.001)$ in M2 pigs than in M12 pigs. Meal frequency also changed
\end{abstract}

$(P<0.001)$ the time-course profiles of plasma concentrations of glucose, insulin, and lactate in response to meal ingestion. A greater rise and a sharper fall in plasma glucose and insulin levels were observed in M2 pigs compared with M12 pigs. In both groups, similarities were observed in the postprandial time courses of plasma concentrations of insulin and of $\alpha$-amino nitrogen (used as a measure of total AA). Despite these metabolic responses, tissue lipids, glycogen content, and enzyme activities participating in energy metabolism in muscle and liver were similar $(P>0.10)$ in both groups at the end of the trial. Percentage of perirenal fat in the body and depth of dorsal subcutaneous fat tissue were not affected by meal frequency, but kidney weight was lower $(-18 \%, P<0.001)$ in M2 pigs than in M12 pigs. Altogether, the less frequent daily meal intake improves the conversion of feed into weight gain, without marked modifications of tissue composition in young pigs.

Key words: energy metabolism, feed efficiency, meal frequency, plasma metabolites, tissue composition

(C) 2014 American Society of Animal Science. All rights reserved.

J. Anim. Sci. 2014.92:2008-2016 doi:10.2527/jas2013-7505

\section{INTRODUCTION}

A better understanding of the nutritional ways to control growth and body composition is of utmost importance in various species, including pigs. Besides caloric intake, meal frequency has been regarded as an additional factor able to affect BW and composition in man (Schwarz et al., 2011). The few studies on this subject in growing pigs have provided somewhat conflicting results on BW and fat gains (O'Hea

\footnotetext{
${ }^{1}$ The authors thank the staff of UMR1348 Pegase (Physiology, Environment and Genetics for the Animal and Livestock Systems) for animal care, surgery, and slaughtering, and S. Tacher and C. Tréfeu for their technical assistance. T. Le Naou was supported by a scholarship from Institut National de la Recherche Agronomique (INRA) and the research fund of Region Bretagne (France)

${ }^{2}$ Corresponding author: florence.gondret@rennes.inra.fr

Received December 16, 2013.

Accepted February 19, 2014.
}

and Leveille, 1969; Allee et al., 1972; Faucitano et al., 2006). Meal frequency did not alter the absorption and digestibility of energy and amino acids in pigs (Ruckebusch and Bueno, 1976, Chastanet et al., 2007). Therefore, the partitioning of energy and its forms of storage (glycogen or lipids) are central to the possible effects of meal frequency on weight management and composition. Indeed, limited access to feed during the day constrains the intermediary metabolism to alternate between storage and use of nutrients to ensure a continuous supply of energy to cells in the meal intervals. The observation of an enhanced lipogenesis in adipose tissue of pigs fed 1 or 2 daily meals as compared with nibbling pigs (Allee et al., 1972; Romsos et al., 1978) supports this view. The conversion of carbohydrates to lipids is, however, energetically less efficient than storage as glycogen (van Milgen, 2002). Thus, it may be theorized that daily meal frequency could affect the 
conversion of feed into weight gain. In support, pigs selected for a high muscle gain and fed 6 times daily during $42 \mathrm{~d}$ had a greater feed efficiency than pigs fed twice a day (Schneider et al., 2011). Older studies had shown that pigs fed a single daily meal were more efficient than nibblings (Allee et al., 1972) or reported no difference between single and multiple feeders (Friend and Cunningham, 1964).

This study aimed to determine the effects of meal frequency on circulating nutrients and hormones, tissue composition and metabolism, and performance in young growing pigs.

\section{MATERIALS AND METHODS}

The care and use of pigs were performed in compliance with the French guidelines for use of animals in research and the protocol was approved by the local ethical committee (Rennes, France, 2011). The scientific and technical staffs have obtained an agreement from the French veterinary services to conduct animal research.

\section{Animals and Diets}

Thirty-two female pigs of a crossbred genotype $[$ Pietrain $\times($ Large White $\times$ Landrace $)]$ were obtained from 16 litters in the experimental herd of INRA (SaintGilles, France) in 2 successive replicates. At $71 \pm 4 \mathrm{~d}$ of age, 16 pairs of pigs of similar BW $(29 \pm 3 \mathrm{~kg})$ were chosen. Within a pair of littermates, pigs were allocated to 1 of the 2 feeding frequency groups in 2 temperatureregulated $\left(22^{\circ} \mathrm{C}\right)$ rooms $(1$ per treatment). All pigs were individually penned in metal-floor metabolic cages (210 $\times 66 \times 110 \mathrm{~cm}$ ) equipped with an automatic feeder. After an overnight fast, a catheter was surgically inserted in the jugular vein (premedication with Imalgène 1000 $15 \mathrm{mg} / \mathrm{kg}$; Merial, Lyon, France) under general anesthesia (administrated by inhalation with a face mask of sevoflurane; Baxter, Maurepas, France). After surgery, antibiotics ( $4 \mathrm{~mL}$ of $0.5 \mathrm{mg} / \mathrm{ml}$ ampicillin; Coophavet, Ancenis, France) were administrated intramuscularly. The next day, pigs were familiarized with a grower diet of standard composition (Table 1). This diet was mainly based on cereals (wheat, barley, corn), so that feed energy was mainly derived from starch. Diet was offered in a pelleted form and pigs had free access to water. The intervention trial started at $78 \pm 4 \mathrm{~d}$ of age (i.e., after 1 wk of adaptation). It lasted $3 \mathrm{wk}$, so that pigs were $99 \pm 3$ $\mathrm{d}$ of age at the end of the trial. During this interventional period, each pair of littermates received daily a same amount of feed, which was adjusted at $90 \%$ of the estimated ad libitum feed intake per $\mathrm{kg}$ of $\mathrm{BW}^{0.60}$. Within a pair, 1 pig was offered the feed twice daily (M2, $n=$ 16), whereas its littermate was offered the same feed 12
Table 1. Ingredients and chemical composition of the diet

\begin{tabular}{lc}
\hline \hline Ingredients & \% (as fed basis) \\
\hline Wheat & 26.2 \\
Corn & 16.0 \\
Barley & 25.5 \\
Wheat bran & 5.0 \\
Soybean meal & 19.0 \\
Vegetable oil & 2.0 \\
Molasses & 3.0 \\
Calcium carbonate & 1.29 \\
Dicalcium phosphate & 0.50 \\
Salt & 0.45 \\
Vitamin-mineral premix & 0.50 \\
Chemical composition & $\%$ \\
Minerals & 5.6 \\
CP & 16.5 \\
Crude fat & 4.2 \\
Cellulose & 3.8 \\
Starch & 40.9 \\
Nutritional values & \\
SID lysine ${ }^{1}, \%$ & 8.4 \\
Digestible energy, MJ/kg & 13.44 \\
Net energy, MJ/kg & 9.67 \\
\hline
\end{tabular}

${ }^{1}$ Standardized ileal digestible lysine.

times per day (M12, $n=16)$. The M2 group had access to feed during $1 \mathrm{~h}$ at $0800 \mathrm{~h}$ and at $1600 \mathrm{~h}$, respectively; refusals (if any) were removed and weighed. Pigs of the M12 group were fed every $2 \mathrm{~h}$ from $0800 \mathrm{~h}$. Refusals, if any, were removed and weighed at the beginning of each day (0745 h). Daily feed intake was calculated as the difference between the amount of feed distributed and refusals during the intervention trial. Pigs were weighed weekly before the first morning meal at $0800 \mathrm{~h}$ and the day of slaughter. The G:F ratio was then calculated.

\section{Blood Sampling}

Blood samples refered as basal were collected at $0745 \mathrm{~h}$ at $\mathrm{d} 4$ (middle of the first week) and d11 (middle of the second week) of the trial; this meant that M2 pigs received their last meal at $1600 \mathrm{~h}$ the day before, whereas M12 pigs received their last meal at $0600 \mathrm{~h}$. At d18 (middle of the third week) of the trial, a serial blood sampling was performed as follows: the first sampling occurred at $0745 \mathrm{~h}$ and was followed by a second sampling at approximately $0800 \mathrm{~h}$, just after a test meal $(300$ $\mathrm{g}$ of feed in each group) had been consumed completely. Sampling continued for every $10 \mathrm{~min}$ the first hour and every $15 \mathrm{~min}$ the second hour. The sampling ended at 105 min after ingestion of the test meal, which corresponds to the interval between 2 successive meals in M12 pigs. The sampling at $0745 \mathrm{~h}$ corresponded again to the basal point, whereas serial samples collected after the ingestion of the test meal were used to evaluate the 
time-course profiles of nutrients and hormones. Blood samples (10 mL per sample; collected on EDTA) were stored on ice before centrifugation $\left(+4^{\circ} \mathrm{C}\right)$ during 15 min at $2500 \times \mathrm{g}$. Collected plasma was then stored at $-20^{\circ} \mathrm{C}$ until nutrient and hormone concentration analyses.

\section{Tissue Sampling}

Pigs were killed at $99 \pm 3 \mathrm{~d}$ of age. On the day of slaughter, pigs were offered $800 \mathrm{~g}$ feed as a single meal. Four hours after this meal, pigs were killed immediately by electronarcosis and jugular exsanguination. Digestive and respiratory tracts, heart, kidneys, liver, spleen, perirenal adipose tissue, and the flanks (muscle parts with membranes) were removed before the hot carcass was weighed. The liver, kidneys, flanks, and perirenal fat pads were also weighed. Depth of the dorsal subcutaneous adipose tissue (SCAT) was assessed at the third lumbar vertebra level from the left-half carcass with a ruler. Samples of liver, perirenal adipose tissue, SCAT (at the last rib level) and of the LM (last rib level) were collected from the right half-carcass within $15 \mathrm{~min}$ after death. All samples were cut into small pieces, snap frozen in liquid nitrogen, and stored at $-75^{\circ} \mathrm{C}$ until biochemical analyses.

\section{Plasma Nutrients and Hormone Concentrations}

Plasma concentrations of glucose, lactate, triglyceride, NEFA, urea, albumin, and protein were determined in duplicate using a Konelab 20i apparatus (Thermo Fisher Scientific, Courtaboeuf, France). Glucose (Glucose RTUTM $^{\mathrm{TM}}$ ), lactate (Lactate PAP-colorimetric ${ }^{\mathrm{TM}}$ ), triglyceride (Triglycérides Enzymatique PAP 150), urea, protein, and albumin kits were obtained from BioMérieux (Craponne, France). The NEFA kit (NEFA)-HR(2) was purchased from Wako Chemicals GmbH (Neuss, Germany). Plasma $\alpha$-amino nitrogen concentration was measured after plasma deproteinization using a colorimetric method (Chacornac et al., 1993). Intraassay coefficients of variation for measurements were below 5\%. Radioimmunoassay kits were used to measure plasma concentrations of insulin and leptin (Qian et al., 1999). Kits for insulin and leptin (multi-species kit, Linco) were obtained from CIS bio International (Gif-surYvette, France) and Labodia (Paris, France), respectively. Intraassay coefficients of variation were below $7 \%$.

\section{Biochemical Tissue Composition}

Lipid content in the 2 adipose tissues was determined after a 2:1 chloroform/methanol extraction procedure (Folch et al., 1957). Glycogen content was determined in the liver and LM (Good et al., 1933) with minor adaptations as follows. A tissue sample of
$250 \mathrm{mg}$ was mixed in a $1 \mathrm{M} \mathrm{HCl}$ solution in a nitrogen steam. Then, the homogenate was put in a water bath at $100^{\circ} \mathrm{C}$ for $2.5 \mathrm{~h}$ to hydrolyze the glycogen. This solution was then neutralized using a $5 \mathrm{M} \mathrm{KOH}$ solution. The volume was adjusted to $25 \mathrm{~mL}$ with a $0.2 \mathrm{M}$ phosphate buffer ( $\mathrm{pH}=7.4)$. Glucose concentrations in the neutralized and hydrolyzed solutions were then measured using the Konelab 20i apparatus. Glycogen concentration was calculated using reference values obtained by hydrolyzing pure glycogen into glucose using the same method.

\section{Enzyme Assays}

Activities of L-lactate dehydrogenase (LDH; E.C. 1.1.1.27) participating to glycolysis/gluconeogenesis, 3-hydroxylacyl-CoA dehydrogenase (HAD; E.C. 1.1.1.35) involved in fatty acid degradation, and citrate synthase (CS; E.C. 2.3.3.1) in the mitochondrial citrate cycle, were monitored in the liver and LM. Briefly, samples (approximately $30 \mathrm{mg}$ ) were homogenized in $0.1 \mathrm{M}$ phosphate buffer $(\mathrm{pH}=7.4)$ containing $2 \mathrm{mM}$ EDTA. Mixtures were sonicated $(60 \mathrm{~s}, 50 \mathrm{~Hz})$ and centrifuged $\left(13 \mathrm{~min}, 1500 \times g,+4^{\circ} \mathrm{C}\right)$. Supernatants were stored on ice. Activities were immediately assayed spectrophotometrically at $340 \mathrm{~nm}$ absorbance for LDH (Vassault, 1983) and HAD (Bass et al., 1969) and at $405 \mathrm{~nm}$ absorbance for CS (Srere, 1969).

\section{Statistical Analysis}

The effects of meal frequency on growth performance, body and tissue composition, and enzyme activities were analyzed by ANOVA with the MIXED procedure of SAS (SAS Inst. Inc., Cary, NC), considering meal frequency (M2 or M12) and replicate (first or second replicates) as the main effects. Plasma nutrient and hormone concentrations obtained from the serial blood sampling were analyzed by the MIXED procedure with meal frequency, replicate, a repeated statement for sampling time, and the interaction between meal frequency and time as the main effects (Littell et al., 1998). The basal concentrations in plasma nutrients were analyzed as described for concentrations at the serial blood sampling points, except that in this case, the repeated statement corresponded to the week of sampling. Differences between meal frequency groups were considered significant for $P \leq 0.05$, and $0.05<P \leq$ 0.10 was discussed as a trend. 
Table 2. Growth and feed efficiency of pigs fed 12 (M12) or 2 (M2) times a day during a 3-wk intervention period ${ }^{1}$

\begin{tabular}{lcccc}
\hline \hline & M12 & M2 & SE & $P$-value \\
\hline Initial BW, kg & 30.0 & 30.0 & 0.7 & 0.963 \\
Final BW, kg & 52.0 & 53.5 & 0.8 & 0.187 \\
ADG, g/d & 796 & 850 & 13 & 0.009 \\
Daily food consumption, g/d/kg BW 0.60 & 162 & 164 & 10 & 0.351 \\
Gain to feed ratio & 0.51 & 0.53 & 0.01 & 0.050 \\
\hline
\end{tabular}

${ }^{1}$ Data are presented as means together with standard errors (SE). $P$-value, level of significance of the difference between the M12 and M2 groups $(n=$ 16 per group).

\section{RESULTS}

\section{Effects of Meal Frequency on Growth and Tissue Composition}

The daily feed intake (scaled to metabolic BW) was experimentally imposed to be similar in M2 and M12 groups. As shown in Table 2, the less frequent meal strategy resulted in an accelerated $(P<0.01)$ ADG for M2 pigs $(+47 \mathrm{~g} / \mathrm{d})$ when compared with M12 pigs. Consequently, young pigs fed twice a day demonstrated an improved $\mathrm{G}: \mathrm{F}(P=0.05)$ as compared to their pairfed counterparts receiving 12 meals per day. At the end of the trial, the weights of the hot carcass, liver, and heart did not differ between M2 and M12 groups. However, kidney weight was the lowest $(P<0.001)$ in M2 pigs (Table 3). Conversely, the flanks tended to be heavier $(+12 \mathrm{~g} ; P=0.06)$ in $\mathrm{M} 2$ pigs than in M12 pigs. Perirenal fat weight also tended $(P<0.10)$ to be greater in M2 pigs than in M12 pigs, but its proportion in the body was rather similar $(P=0.27)$ in both groups $(0.47 \%$ and $0.43 \%$ in M 2 and M12 pigs, respectively). Fat depth at the dorsal subcutaneous level as well as tissue lipid contents did not differ between M2 and M12 groups. In addition, glycogen contents in the liver and LM were also similar in both groups (Table 3). Finally, the specific activities of enzymes related to energy use in tissues did not differ between M2 and M12 strategies.

\section{Effects of Meal Frequency on Basal Concentrations of Plasma Nutrients}

Morning basal plasma concentrations of glucose, lactate, triglycerides, urea, and albumin were the lowest $(P<0.001)$ for pigs receiving less frequent daily meals (Table 4). However, treatment-related difference in glycaemia was attenuated along the trial duration $(P=0.022$ for the interaction between meal frequency strategy and time). Similarly, the ranges of differences between treatments for lactate, triglycerides, albumin, and urea plasma concentrations were generally larger in the first week after the experiment had started than thereafter (Table 4).
Table 3. Body composition and tissue traits in pigs fed 12 (M12) or 2 (M2) times a day after a 3-wk intervention period ${ }^{1}$

\begin{tabular}{|c|c|c|c|c|}
\hline$\overline{\text { Item }^{2}}$ & M12 & M2 & $\mathrm{SE}$ & $P$-value \\
\hline Carcass weight, $\mathrm{kg}$ & 38.6 & 40.1 & 0.6 & 0.114 \\
\hline \multicolumn{5}{|l|}{ Organs weight, $g$} \\
\hline Liver & 1,113 & 1,108 & 22 & 0.869 \\
\hline Heart & 209 & 220 & 5 & 0.125 \\
\hline Flanks (muscle parts with membranes) & 152 & 164 & 5 & 0.060 \\
\hline Kidney & 224 & 190 & 6 & $<0.001$ \\
\hline \multicolumn{5}{|l|}{ Perirenal adipose tissue } \\
\hline Weight, g & 222 & 252 & 12 & 0.093 \\
\hline Lipid content, $\%$ fresh tissue & 66.9 & 70.0 & 3.6 & 0.550 \\
\hline \multicolumn{5}{|l|}{ Subcutaneous adipose tissue } \\
\hline Depth, mm & 13.2 & 12.5 & 0.7 & 0.414 \\
\hline Lipid content, $\%$ fresh tissue & 62.2 & 64.2 & 1.5 & 0.353 \\
\hline \multicolumn{5}{|l|}{ LM } \\
\hline Glycogen content, $\%$ & 1.37 & 1.33 & 0.06 & 0.634 \\
\hline LDH activity, $\mu \mathrm{mol} / \mathrm{min} / \mathrm{g}$ tissue & 1,708 & 1,675 & 66 & 0.725 \\
\hline $\mathrm{HAD}$ activity, $\mu \mathrm{mol} / \mathrm{min} / \mathrm{g}$ tissue & 3.18 & 2.90 & 0.15 & 0.194 \\
\hline $\mathrm{CS}$ activity, $\mu \mathrm{mol} / \mathrm{min} / \mathrm{g}$ tissue & 6.43 & 6.70 & 0.45 & 0.731 \\
\hline \multicolumn{5}{|l|}{ Liver } \\
\hline Glycogen content, $\%$ & 5.25 & 6.40 & 0.51 & 0.132 \\
\hline LDH activity, $\mu \mathrm{mol} / \mathrm{min} / \mathrm{g}$ tissue & 65.9 & 62.4 & 2.4 & 0.306 \\
\hline $\mathrm{HAD}$ activity, $\mu \mathrm{mol} / \mathrm{min} / \mathrm{g}$ tissue & 18.6 & 17.1 & 4.7 & 0.820 \\
\hline $\mathrm{CS}$ activity, $\mu \mathrm{mol} / \mathrm{min} / \mathrm{g}$ tissue & 9.44 & 9.78 & 0.28 & 0.411 \\
\hline
\end{tabular}

${ }^{1}$ Data are presented as means together with standard errors (SE). $P$-value, level of significance of the difference between M12 and M2 pigs ( $n=16$ per group).

${ }^{2} \mathrm{CS}=$ citrate synthase; $\mathrm{HAD}=3$-hydroxylacyl-CoA dehydrogenase; $\mathrm{LDH}=$ L-lactate dehydrogenase.

Irrespective of sampling week, basal plasma concentrations in NEFA, and total proteins did not differ between M2 and M12 pigs (Table 4).

\section{Effects of Meal Frequency on Postprandial Patterns of Plasma Nutrients}

In both groups, daily meal frequency altered $(P<$ $0.01)$ the time course of plasma concentrations of glucose and lactate recorded after a meal test. In M2 pigs, plasma glucose concentration increased $(P<0.05)$ $10 \mathrm{~min}$ after meal ingestion to reach a peak at $20 \mathrm{~min}$ postprandially (Fig. 1A); then it dropped abruptly to values similar $(P>0.10)$ to baseline. In M12 pigs, plasma glucose concentration increased more regularly after ingestion of the test meal, to reach a maximum around 60 min postprandially; thereafter, it gradually decreased. Thus, plasma glucose concentrations were significantly lower $(P<0.05)$ in M2 pigs than in M12 pigs just after meal ingestion and again between 45 and 90 min postprandially. The time-course profile in plasma lactate concentration was somewhat similar to that of glucose. In M2 pigs, a peak in plasma lactate concentration was observed at 40 min postprandially, before plasma lactate 
Table 4. Basal plasma nutrient concentrations for pigs fed 12 (M12) or 2 (M2) times a day assessed at the middle of the first, second, and third weeks of the trial ${ }^{1}$

\begin{tabular}{|c|c|c|c|c|c|c|c|}
\hline \multirow{2}{*}{$\begin{array}{l}\text { Design } \\
\text { Items }\end{array}$} & \multirow[b]{2}{*}{ Week } & \multicolumn{2}{|c|}{ Meal frequency } & \multirow[b]{2}{*}{ SE } & \multicolumn{3}{|c|}{$P$-value ${ }^{2}$} \\
\hline & & M12 & M2 & & Treatment & Week & $\mathrm{T} \times \mathrm{wk}$ \\
\hline \multirow[t]{2}{*}{$\overline{\text { Glucose, }, \mathrm{g} / \mathrm{L}}$} & 1 & $1.06 \mathrm{ac}^{3}$ & $0.88 \mathrm{~b}$ & 0.03 & $<0.001$ & $<0.001$ & 0.022 \\
\hline & 3 & $1.03 \mathrm{ac}$ & $1.00 \mathrm{c}$ & 0.03 & & & \\
\hline \multirow[t]{2}{*}{ Lactate, $\mathrm{mmol} / \mathrm{L}$} & 1 & $1.34 \mathrm{a}$ & $0.92 \mathrm{c}$ & 0.07 & $<0.001$ & 0.003 & 0.081 \\
\hline & 2 & $1.57 \mathrm{~b}$ & $0.91 \mathrm{c}$ & 0.07 & & & \\
\hline \multirow[t]{3}{*}{$\mathrm{NEFA}, \mu \mathrm{mol} / \mathrm{L}$} & 1 & 125 & 104 & 25 & 0.844 & 0.197 & 0.146 \\
\hline & 2 & 111 & 96 & 15 & & & \\
\hline & 3 & 73 & 100 & 9 & & & \\
\hline \multirow[t]{3}{*}{ Triglycerides, mg/L } & 1 & $401 \mathrm{a}$ & $242 b$ & 30 & $<0.001$ & 0.560 & 0.588 \\
\hline & 2 & $442 \mathrm{a}$ & $237 b$ & 30 & & & \\
\hline & 3 & $427 \mathrm{a}$ & $280 \mathrm{~b}$ & 31 & & & \\
\hline \multirow[t]{3}{*}{ Albumin, $\mathrm{g} / \mathrm{L}$} & 1 & $39.5 \mathrm{a}$ & $33.4 \mathrm{bd}$ & 1.2 & $<0.001$ & $<0.001$ & 0.175 \\
\hline & 2 & $35.6 \mathrm{~b}$ & $32.4 d$ & 1.2 & & & \\
\hline & 3 & $43.4 \mathrm{c}$ & $41.7 \mathrm{ac}$ & 1.2 & & & \\
\hline \multirow[t]{3}{*}{ Urea, mg/L } & 1 & $234 \mathrm{a}$ & $165 \mathrm{~b}$ & 13 & $<0.001$ & 0.295 & 0.830 \\
\hline & 2 & $234 \mathrm{a}$ & $177 \mathrm{~b}$ & 10 & & & \\
\hline & 3 & $248 \mathrm{a}$ & $194 b$ & 15 & & & \\
\hline
\end{tabular}

${ }^{1}$ Basal concentrations referred to values measured in plasma at $0745 \mathrm{~h}$ (i.e., just before the first morning meal of M2 pigs). Data are presented as means together with standard errors (SE).

${ }^{2} P$ values: levels of significance for the differences due to treatment (M2 vs. M12), week after the initiation of experiment (1,2, or 3 wk), and the interaction between feeding frequency and week (treatment $\times$ week).

${ }^{3} \mathrm{a}, \mathrm{b}, \mathrm{c}, \mathrm{d}$ : means with a different letter differ $(P<0.05)$.

concentration rapidly declined to reach the baseline between 75 and 90 min postprandially (Fig. 1B). In M12 pigs, there were no time-associated variations in plasma lactate concentrations. Therefore, plasma lactate level at maximum was clearly greater $(P<0.001)$ in M2 pigs than in M12 pigs, whereas basal lactate concentration in plasma was slightly lower in the pigs fed less frequently compared with M12 pigs.

There were no time-associated fluctuations in plasma triglyceride concentrations in the 2 groups, so that triglyceridemia was always lower $(P<0.05)$ in M2 pigs than in M12 pigs (Fig. 2A). By contrast, meal frequency altered $(P<0.01)$ the postprandial time course in plasma NEFA concentrations. Indeed, in M2 pigs, NEFA plasma concentration immediately fell after meal ingestion to reach a minimum value from 30 min postprandially onward (Fig. 2B). In M12 pigs, plasma NEFA concentrations did not vary after meal ingestion.

The plasma level of urea (Fig. 3A), as well as plasma concentrations in total proteins and albumin (data not shown), did not vary after meal ingestion. Across the sampling kinetics, plasma urea concentrations were clearly lower $(P<0.001)$ in M2 pigs than in M12 pigs (251 mg/L vs. $192 \mathrm{mg} / \mathrm{L}$, respectively). Importantly, plasma concentration of $\alpha$-amino nitrogen, which reflects total plasma AA concentration, was dependent both on time and treatment (Fig. 3B). In M2 pigs, plasma concentration of $\alpha$-amino nitrogen reached its maximum value $20 \mathrm{~min}$ after meal. It then dropped rapidly, although concentrations remained greater $(P<0.05)$ than basal values during the entire sampling period. In M12 pigs, plasma concentrations of $\alpha$-amino nitrogen remained almost similar to basal value up to $60 \mathrm{~min}$ postprandially; at this time, a slight decrease in plasma concentrations of $\alpha$-amino nitrogen was observed up to values lower than basal concentration. Except at the peak, the plasma concentration of $\alpha$-amino nitrogen was lower $(P<0.001)$ in M2 pigs than in M12 pigs.

\section{Meal Frequency and Plasma Insulin Concentration}

Plasma insulin concentrations also varied with time and daily meal frequency (Fig. 3C). In M2 pigs, plasma insulin concentration increased $(P<0.05)$ immediately after the test meal and peaked at 20 min postprandially. It decreased rapidly thereafter, but remained greater $(P<$ $0.05)$ than the basal concentration. In M12 pigs, there was no increase in plasma insulin concentration after the 
A.

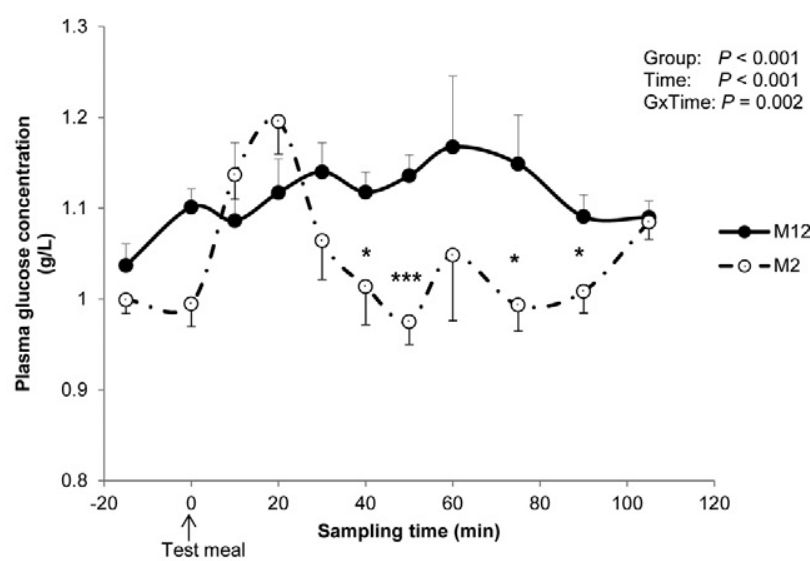

B.

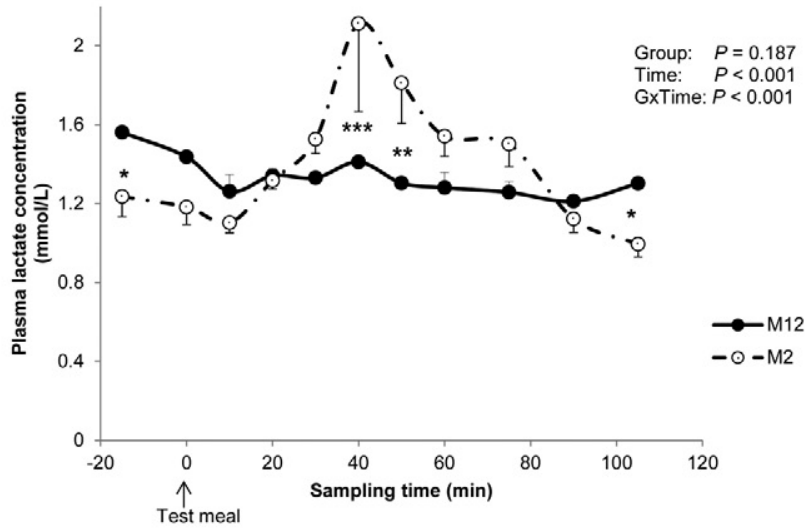

Figure 1. Postprandial responses of plasma glucose (A) and lactate (B) concentrations to a test meal in pigs fed 12 (M12) or 2 (M2) times a day during the 3 preceding weeks. An arrow indicates the moment when pigs were fed the test meal. Within each time, M2 and M12 values differed significantly at $* P<0.05, * * P<0.01, * * * P<0.001$

test meal, and plasma insulin concentrations from $90 \mathrm{~min}$ onward were even lower $(-25 \%$ to $-30 \% ; P<0.10)$ than basal concentration. Whereas pretest plasma insulin concentration was the lowest $(P<0.001)$ in $\mathrm{M} 2$ pigs, the postprandial concentrations in insulin were greater until 105 min postprandially in that group compared with M12 pigs. Plasma leptin concentration did not vary with time after meal ingestion (data not shown). Across time, leptinemia was $20 \%$ lower $(P<0.001)$ in M2 pigs than in M12 pigs (1.9 vs. $2.3 \mathrm{ng} / \mathrm{mL}$, respectively).

\section{DISCUSSION}

Among the various nutritional factors affecting weight gain and tissue composition, little attention has been paid to meal frequency in growing subjects, especially when species other than humans (La Bounty et al., 2011) and rats (Cohn, 1963; Hill et al., 1988; Verbaeys et al., 2011) are considered. Moreover, data on body composition, nutrient use and tissue metabolism have rarely
A.
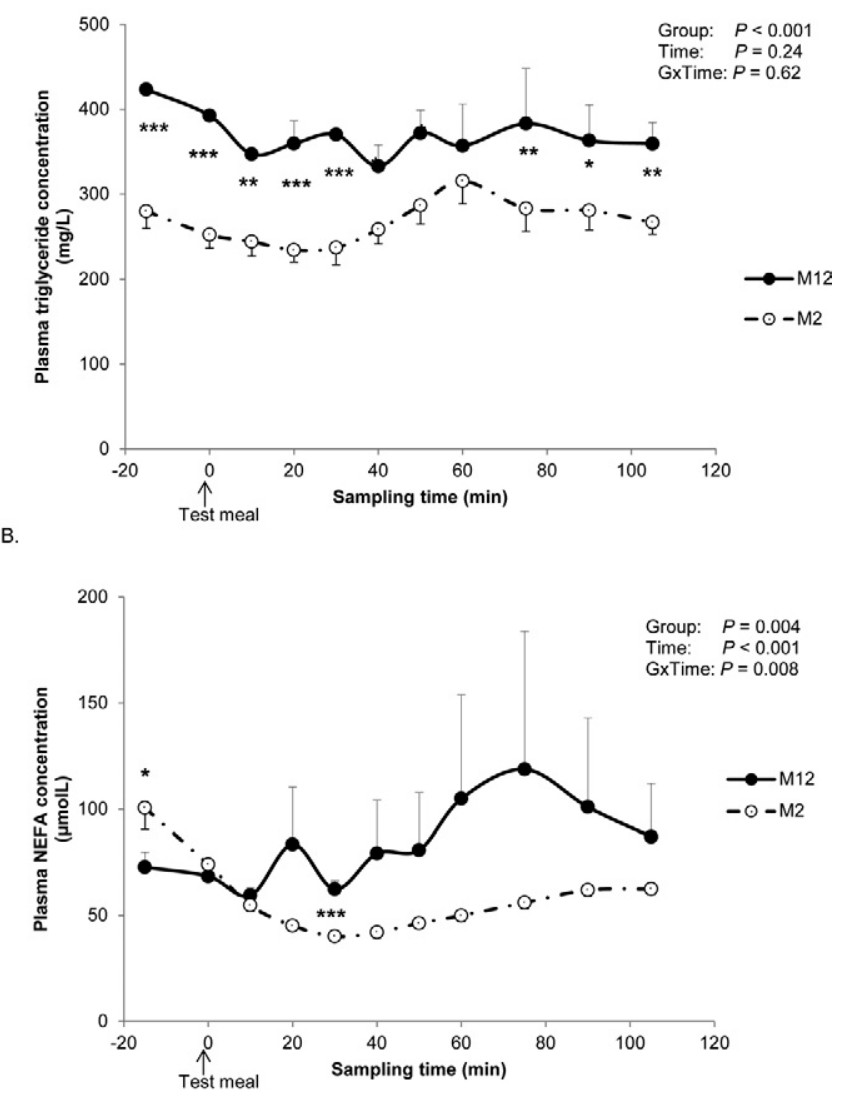

Figure 2. Postprandial responses of plasma triglycerides (A) and nonesterified fatty acids (B) concentrations to a test meal in pigs fed 12 (M12) 2 (M2) times a day during the 3 preceding weeks. An arrow indicates the moment when pigs were fed the test meal. Within each time, M2 and M12 values differed significantly at $* P<0.05, * * P<0.01, * * * P<0.001$.

been acquired within the same study, which limits the comprehensive view of the biological responses to meal frequency due to confounding factors between studies.

\section{Less Frequent Meals Promote Weight Gain and Feed Efficiency without Changes in Lipid Contents}

In the age range considered in this study, young growing pigs may visit the feeders up to 15 times per day (Estany et al., 2002). Therefore, offering 12 meals daily can be considered as a realistic reference for their spontaneous eating behavior. We show that less frequent meal consumption (twice daily) increased weight gain of pigs, but this did not markedly change their body composition. This latter result disagrees with earlier experiments showing a greater fat proportion in the carcass of nibbling pigs compared with meal-fed pigs (O'Hea and Leveille, 1969; Allee et al., 1972). However, in the above-mentioned studies, the amount of daily feed was not adjusted between treatments, so that the response in terms of fat gain might be partly related to the total amount of feed consumed in each groups (Friend and Cunningham, 1964) rather than to the frequency of in- 


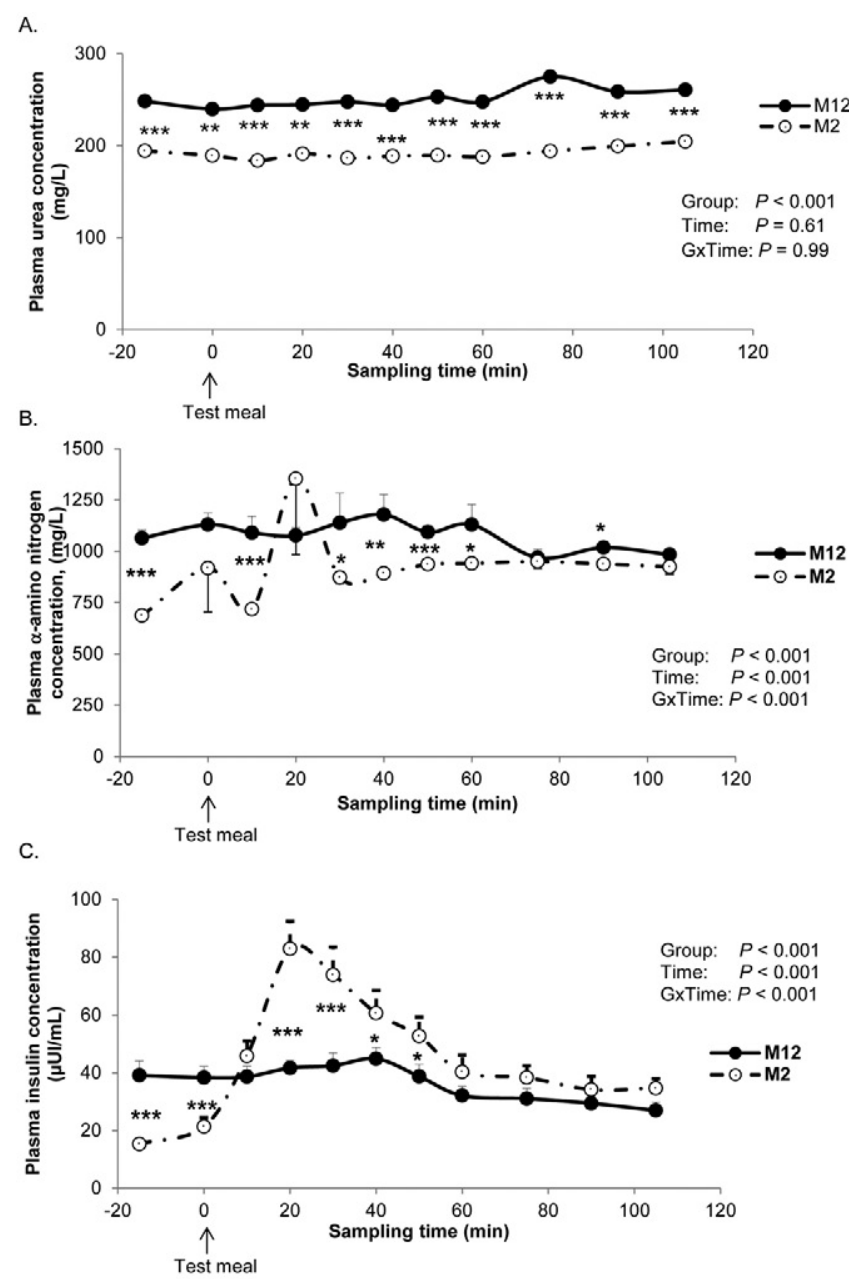

Figure 3. Postprandial responses of plasma urea (A), $\alpha$-amino-nitrogen (B,) and insulin (C) concentrations to a test meal in pigs fed 12 (M12) or 2 (M2) times a day during the 3 preceding weeks. An arrow indicates the moment when pigs were fed the test meal. Within each time, M2 and M12 values differed at $* P<0.05,{ }^{*} P<0.01,{ }^{*} * * P<0.001$.

gested food. When reasoning at the same feed intake, the lack of changes observed herein with daily meal frequency for perirenal fat proportion and lipid contents in adipose tissues is in agreement with another study in growing pigs showing that lipid content in the empty body did not vary when pigs were fed 2 vs. 5 meals a day (Sharma et al., 1973). Similarly, body composition was unchanged in rats fed 2 vs. 10 to 12 meals at $80 \%$ of their usual food intake (Hill et al., 1988). Meal frequency probably did not change body composition of young animals, especially when genotypes capable of rapid lean growth are used. It could be hypothesized that only a prolonged strategy applied to more mature animals could markedly affect adipose tissue accretion. The greater leptinemia in M12 pigs than in M2 pigs confirms recent data in overweight human subjects showing that consuming diet more frequently throughout the day increased the basal plasma concentration of leptin (Arciero et al., 2013). This difference may be associated with glucose metabolism and insulin action (Kraus et al.,
2010) rather than to body fat content. In support, previous results had shown a lack of relationships between plasma leptin concentration and fat mass when young pigs are considered (Morise et al., 2011).

The detrimental effect of frequent daily meals on pig's efficiency is not in accordance with our initial assumption that consuming more meals per day could be at a metabolic advantage. The opposite response observed herein could be associated with effects of meal frequency at the whole-animal level, such as greater maintenance requirements for pigs receiving a high number of meals compared with those fed twice daily (Sharma et al., 1973), greater energy needs for digestion when very frequent meals are fed due to the thermic effect of feed, or differences in activity and energy expenditure between those pigs. In support of this latter aspect, pigs (Friend and Cunningham, 1964; Sharma et al., 1973) and rats (Leveille and O'Hea, 1967) fed once or twice daily were generally less sensitive to the excitation associated with the distribution of feed than animals receiving multiple small meals. Consequently, M2 pigs may have lower energy expenditure than M12 pigs, although an effect of meal frequency on this latter parameter is often not statistically significant in other species (Hill et al., 1988; La Bounty et al., 2011).

\section{Postprandial Fluctuations in Plasma Concentrations of Glucose, Insulin and a-amino Nitrogen were Greater in Pigs Eating Less-Frequent Meals}

To gain insight into the metabolic processes involved in feed utilization with daily meal frequency, the timecourse changes in plasma nutrients and anabolic hormones were compared between M2 pigs and M12 pigs after a meal test of a similar size in both groups. Obviously, the metabolic situation when the morning test meal was distributed was not the same between M2 and M12 pigs, but this corresponds exactly to the situation encountered the previous days by the pigs. The peak in plasma glucose concentration, which is expected to occur shortly after the morning meal ingestion (Koopmans et al., 2005), was observed for M2 pigs only. Because insulin is secreted primarily in response to an elevated blood glucose concentration, the postprandial concentrations in plasma insulin followed that of glucose, with the highest rise and a more accentuated fall in the low-frequency fed pigs than in M12 pigs. These observations are in accordance with data in man, where low feeding frequency ( 3 meals a day) had resulted in higher peaks and lower troughs of glucose and insulin levels compared with greater meal frequency (14 meals a day) under isoenergetic conditions (Munsters and Saris, 2012). Similarly, 2 meals per day led to greater fluctuations of glucose and insulin compared with 12 meals per day in this species (Solomon et al., 2008). The attenuated and delayed increase in plasma glucose concentration 
observed after the meal test in M12 pigs is probably the consequence of decreased stomach distension and reduced rate of stomach emptying with the ingestion of smaller and more frequent meals. This probably resulted in a slower rate of glucose delivery to the intestine (Palmer et al., 2009) as well as in a reduced insulin production. The rapid fall of plasma glucose levels after meal ingestion in M2 pigs suggests a higher clearance of circulating blood glucose by tissues, which is in agreement with studies in rats showing that glucose was removed faster from the circulation when having a limited access to a single meal during a limited period per day compared with nibblers (Leveille and Chakrabarty, 1968; Romsos and Leveille, 1974).

However, the lack of differences in hepatic and muscle glycogen contents does not match our initial assumption that the timing of blood glucose availability would change the form of energy storage in tissues. Because tissue composition was assessed $4 \mathrm{~h}$ after the last meal intake, this does not preclude more rapid changes in the dynamics of glycogen storage and utilization in response to meal frequency, a response that has been previously observed in rats (Leveille, 1966). Similarly, enzyme activities involved in nutrient oxidation in the liver and skeletal muscle, which represent the potential of activities with optimal supply of substrates and cofactors, did not vary in response to meal frequency. A recent study in lean healthy men corroborates these last results, showing that decreased feeding frequency induced greater fluctuations in glucose concentration than control strategy without modifying carbohydrate and fat oxidation (Munsters and Saris, 2012).

Finally, meal-frequency-induced differences in the postprandial pattern of insulin concentrations may have affected the cellular actions of insulin, not only considering energy metabolism (Allee et al., 1972), but also protein metabolism. Indeed, protein and AA metabolism have probably also been affected by daily meal frequency in growing pigs, with lower plasma concentrations of urea and $\alpha$-amino nitrogen in M2 pigs than in M12 pigs. We suggest that less-frequent meals may have i) increased AA utilization for protein synthesis and ii) lowered AA mobilization from protein and AA catabolism. First, the possibility that less-frequent meals may stimulate protein synthesis in growing pigs is supported, at least in part, by the greater weight gain of M2 pigs $(+51 \mathrm{~g} / \mathrm{d})$ along the feeding trial, which was associated with their numerically greater carcass weight at slaughter and a significantly greater weight of the flanks (muscular parts) in that group compared with M12 pigs. The similarities in plasma responses for $\alpha$-amino nitrogen (used as a measure of total AA) and insulin concentrations support the view that feeding-induced stimulation of protein synthesis in skeletal muscle is regulated by both insulin and amino acids in young pigs (Davis et al., 1998, 2002).
Second, the decrease in protein and AA catabolism with les- frequent daily meals in growing pigs is postulated according to the reduction of plasma urea concentration in M2 pigs. This assumption is however opposite to findings in man, where fewer meals had resulted in an increased AA catabolism (Munsters and Saris, 2012). However, in this case, one can claim for differences in the capacity to store AA into proteins in between growing animals (present experiment) and compared with adult subjects. Altogether, because Le Bellego et al. (2001) observed no effects of daily meal frequency (7 vs. 2) on $\mathrm{N}$ utilization in pigs, in vivo measurements of protein synthesis using tracers and measurements of key enzymes in protein catabolism should be realized to further clarify the effects of daily meal frequency on protein metabolism. Finally, the greater weight of kidney in M12 pigs may be also related to a greater urea clearance in this group, and this may again have contributed to greater energy expenditure (Anugwa et al., 1989) in the morefrequently fed pigs than in pigs fed twice daily.

\section{Implications}

These data indicate that less-frequent meal strategy in growing pigs resulted in an enhanced metabolic flexibility, which was mainly illustrated by greater daily fluctuations in plasma glucose, insulin, and $\alpha$-amino nitrogen levels. However, eating large but infrequent meals did not change tissue metabolic capacity, nor the tissue composition and body fat content compared with eating frequent small meals. At a standardized energy intake, it is suggested that feeding twice a day during a limited time may be an additional opportunity to increase growth rate and pigs' efficiency. These data add references to understand the transformation of feed energy in the context of BW management for the ongoing development of precision farming. Other studies could be conducted in the future to compare the metabolic responses to meal frequency between young vs. more mature pigs with a better propensity to develop adipose tissue, or by varying the nutrient composition of the meals (such as the level of crude proteins).

\section{LITERATURE CITED}

Allee, G. L., D. R. Romsos, G. A. Leveille, and D. H. Baker. 1972. Metabolic adaptation induced by meal-eating in the pig. J. Nutr. 102:1115-1122.

Anugwa, F. O., V. H. Varel, J. S. Dickson, W. G. Pond, and L. P. Krook. 1989. Effects of dietary fiber and protein concentration on growth, feed efficiency, visceral organ weights and large intestine microbial populations of swine. J. Nutr. 119:879-886.

Arciero, P. J., M. J. Ormsbee, C. L. Gentile, B. C. Nindl, J. R. Brestoff, and M. Ruby. 2013. Increased protein intake and meal frequency reduces abdominal fat during energy balance and energy deficit. Obesity (Silver Spring) 21:1357-1366. 
Bass, A., D. Brdiczka, P. Eyer, S. Hofer, and D. Pette. 1969. Metabolic differentiation of distinct muscle types at the level of enzymatic organization. Eur. J. Biochem. 10:198-206.

Chacornac, J. P., J. Barnouin, and M. L. Houlier. 1993. An automated micromethod for the determination of plasma-free amino-groups using a discrete computerized analyzer. Reprod. Nutr. Dev. 33:99-108.

Chastanet, F., A. A. Pahm, C. Pedersen, and H. H. Stein. 2007. Effect of feeding schedule on apparent energy and amino acid digestibility by growing pigs. Anim. Feed Sci. Technol. 132:94-102.

Cohn, C. 1963. Feeding frequency and body composition. Ann. N. Y. Acad. Sci. 110:395-409.

Davis, T. A., D. G. Burrin, M. L. Fiorotto, P. J. Reeds, and F. Jahoor. 1998. Roles of insulin and amino acids in the regulation of protein synthesis in the neonate. J. Nutr. 128:347S-350S.

Davis, T. A., M. L. Fiorotto, D. G. Burrin, P. J. Reeds, H. V. Nguyen, P. R. Beckett, R. C. Vann, and P. M. O'Connor. 2002. Stimulation of protein synthesis by both insulin and amino acids is unique to skeletal muscle in neonatal pigs. Am. J. Physiol. Endocrinol. Metab. 282:E880-E890.

Estany, J., D. Villalba, J. Tibau, J. Soler, D. Babot, and J. L. Noguera. 2002. Correlated response to selection for litter size in pigs: I. Growth, fat deposition, and feeding behavior traits. J. Anim. Sci. 80:2556-2565.

Faucitano, L., L. Saucier, J.A. Correa, S. Méthot, A. Giguère, A. Foury, P. Mormède, and R. Bergeron. 2006. Effect of feed texture, meal frequency and pre-slaughter fasting on carcass and meat quality, and urinary cortisol in pigs. Meat Sci. 74:697-703. doi:10.1016/j.meatsci.2006.05.023

Folch, J., M. Lees, and G.H.S. Stanley. 1957. A simple method for the isolation and purification of total lipides from animal tissues. J. Biol. Chem. 226:497-509.

Friend, D. W., and H. M. Cunningham. 1964. Effects of feeding frequency on metabolism, rate and efficiency of gain and on carcass quality of pigs. J. Nutr. 83:251-256.

Good, C. A., H. Kramer, and M. Somogyi. 1933. The determination of glycogen. J. Biol. Chem. 100:485-491.

Hill, J. O., J. C. Anderson, D. Lin, and F. Yakubu. 1988. Effects of meal frequency on energy utilization in rats. Am. J. Physiol. 255:R616-R621.

Koopmans, S. J., J. van der Meulen, R. Dekker, H. Corbijn, and Z. Mroz. 2005. Diurnal rhythms in plasma cortisol, insulin, glucose, lactate and urea in pigs fed identical meals at 12-hourly intervals. Physiol. Behav. 84:497-503.

Kraus, D., M. A. Herman, and B. B. Kahn. 2010. Leveraging leptin for type I diabetes? Proc. Natl. Acad. Sci. USA 107:4793-4794.

La Bounty, P. M., B. I. Campbell, J. Wilson, E. Galvan, J. Berardi, S. M. Kleiner, R. B. Kreider, J. R. Stout, T. Ziegenfuss, M. Spano, A. Smith, and J. Antonio. 2011. International society of sports nutrition position stand: Meal frequency. J. Int. Soc. Sports Nutr. 8:4. doi:10.1186/1550-2783-8-4

Le Bellego, L., J. van Milgen, S. Dubois, and J. Noblet. 2001. Energy utilization of low-protein diets in growing pigs. J. Anim. Sci. 79:1259-1271.

Leveille, G. A. 1966. Glycogen metabolism in meal-fed rats and chicks and the time sequence of lipogenic and enzymatic adaptive changes. J. Nutr. 90:449-460.

Leveille, G. A., and K. Chakrabarty. 1968. Absorption and utilization of glucose by mealfed and nibbling rats. J. Nutr. 96:69-75.
Leveille, G. A., and E. K. O’Hea. 1967. Influence of periodicity of eating on energy metabolism in the rat. J. Nutr. 93:541-545.

Littell, R. C., P. R. Henry, and C. B. Ammerman. 1998. Statistical analysis of repeated measures data using SAS procedures. J. Anim. Sci. 76:1216-1231.

Morise, A., B. Sève, K. Macé, C. Magliola, I. Le Huërou-Luron, and I. Louveau. 2011. Growth, body composition and hormonal status of growing pigs exhibiting a normal or small weight at birth and exposed to a neonatal diet enriched in proteins. Br. J. Nutr. 105:1471-1479.

Munsters, M. J., and W. H. Saris. 2012. Effects of meal frequency on metabolic profiles and substrate partitioning in lean healthy males. PLoS ONE 7:e38632. doi:10.1371/journal.pone.0038632

O'Hea, E. K., and G. A. Leveille. 1969. Influence of feeding frequency on lipogenesis and enzymatic activity of adipose tissue and on the performance of pigs. J. Anim. Sci. 28:336-341.

Palmer, M. A., S. Capra, and S. Baines. 2009. Association between eating frequency, weight and health. Nutr. Rev. 67:379-390.

Qian, H., C. R. Barb, M. M. Compton, G. J. Hausman, M. J. Azain, R. R. Kraeling, and C. A. Baile. 1999. Leptin mRNA expression and serum leptin concentrations as influenced by age, weight, and estradiol in pigs. Domest. Anim. Endocrinol. 16:135-143.

Romsos, D. R., and G. A. Leveille. 1974. Effect of meal frequency and diet composition on glucose tolerance in the rat. J. Nutr. 104:1503-1512.

Romsos, D. R., E. R. Miller, and G. A. Leveille. 1978. Influence of feeding frequency on body weight and glucose tolerance in the pig. Proc. Soc. Exp. Biol. Med. 157:528-530.

Ruckebusch, Y., and L. Bueno. 1976. Effect of feeding on motility of stomach and small-intestine in pig. Br. J. Nutr. 35:397-405.

Schneider, J. D., M. D. Tokach, R. D. Goodband, J. L. Nelssen, S. S. Dritz, J. M. Derouchey, and R. C. Sulabo. 2011. Effects of restricted feed intake on finishing pigs weighing between 68 and 114 kilograms fed twice or 6 times daily. J. Anim. Sci. 89:3326-3333.

Schwarz, N. A., B. Rhett Rigby, P. La Bounty, B. Shelmadine, and R. G. Bowden. 2011. A review of weight control strategies and their effects on the regulation of hormonal balance. J. Nutr. Metab. 2011:237932. doi: 10.1155/2011/237932

Sharma, V. D., L. G. Young, R. G. Brown, J. Buchanan-Smith, and G. C. Smith. 1973. Effects of frequency of feeding on energy metabolism and body composition of young pigs. Can. J. Anim. Sci. 53:157-164. doi:10.4141/cjas73-024

Solomon, T. P., E. S. Chambers, A. E. Jeukendrup, A. A. Toogood, and A. K. Blannin. 2008. The effect of feeding frequency on insulin and ghrelin responses in human subjects. Br. J. Nutr. 100:810-819.

Srere, P. A. 1969. Citrate synthase: [EC 4.1.3.7. Citrate oxaloacetatelyase (CoA-acetylating)]. In: John M. L., editor, Methods in enzymology. Vol. 13. Academic Press, New York. p. 3-11.

van Milgen, J. 2002. Modeling biochemical aspects of energy metabolism in mammals. J. Nutr. 132:3195-3202.

Vassault, A. 1983. Lactate dehydrogenase: UV-method with pyruvate and NADH. In: B. H. U. Bergmeyer, editor, Methods of enzymatic enzymology. Vol. 3. Weinheim, Verlag Chemic, Weinheim, Germany. p. 118-126.

Verbaeys, I., V. Tolle, Q. Swennen, P. Zizzari, J. Buyse, J. Epelbaum, and M. Cokelaere. 2011. Scheduled feeding results in adipogenesis and increased acylated ghrelin. Am. J. Physiol. Endocrinol. Metab. 300:E1103-E1111. 
References

This article cites 37 articles, 19 of which you can access for free at: http://www.journalofanimalscience.org/content/92/5/2008\#BIBL 